\title{
Convocation Address - I
}

\section{T K J Peiris}

(Educationist and eminent researcher - Convocation Address on 19 November 2007)

\section{Miles to go before I sleep}

First and foremost, I wish to express my humble gratitude to all who were instrumental in conferring on me this singular appreciation in the form of an honorary degree of the Open University of Sri Lanka. It is indeed a heartening thought in the twilight of my life to realize that my humble contribution to the progress of education in this country has had wider repercussions than I ever imagined. I thank you most humbly.

Let me now reveal to you a secret. After I was informed that I would be honoured in this way, one night I had a dream. I dreamt that Sri Lanka came to me as a mother and laid bare, her wishes and hopes in the form of attitudes, skills and knowledge she would like to see developed in all her children, both the ones that are already born as well as the ones that will be born in the future to adorn this country as her worthy sons and daughters.

She reminded me of the beautiful poem on Children by the middle Eastern poet, Kahlil Gibran.

You may give them your love but not your thoughts, For they have their own thoughts.

You may house their bodies but not their souls, For their souls dwell in the house of tomorrow, which you cannot visit, not even in your dreams. You may strive to be like them, but seek not to make them like you. For life goes not backward nor tarries with yesterday.

She said 'The future is already upon us. But take heart and dream of a resplendent island peopled by wise, contented caring individuals. She spoke of her past glories and her future hopes in the words of her adopted son, Rev. W.S. Senior in his hauntingly beautiful poem 'Call of Lanka'. 
"He shall sing of sheer Sigiriya

Of Minneriya's wandering kine;

He shall sing of the lake and the lotus

He shall sing of the rock hewn shrine,

Whatsoever is old in Lanka

Shall live in his lordly line.

But most shall he sing of Lanka

In the brave new days that come

When the races all have blended

And the voice of strife is dumb

When we leap to a single bugle

March to a single drum!

In this dream of beautiful peace for our Motherland which could indeed make it-not the teardrop-but the Pearl of the Indian Ocean, she emphasized what our priorities should be for future education of our children. Henceforth I will briefly enumerate some of these features.

First will be Mental and Psychological Skills which we should foster. Although the rapidly changing future is not directly evident to us, one thing is certain. Our children will not definitely need chunks of knowledge as now learnt by heart for the narrow purpose of passing examinations. Vast stores of knowledge are already available at our finger tips through e-mail, internet, and other rapid technological advances of today. These advances are multiplying daily and the founts of knowledge are bombarding the reader at a mighty pace.

What the future citizens need will not be ability to memorise but the Wisdom to analyze, to consider pros and cons, to compare, extrapolate and predict, to synthesize and evaluate. Wisdom to make decisions will be an absolutely necessary condition even for survival in a fiercely competitive society, let alone to prospering and doing well. True wisdom, it is said, is the essence that remains after all the details one has learnt are forgotten.

Future men and women will have to cope with complex and unforeseen circumstances in order to achieve a sense of security and stability. This will be all the more difficult because rapid change in all spheres will be the only certain element in forecasting. Hence the following eternally true prayer will gain more meaning.

Please give me the courage to change what needs to be changed, the strength to retain what should be retained and the wisdom to differentiate between the two'. 
The Awareness should be developed in children that the world is becoming more complex and uncertain by the minute. In fact in the future people may not speak of the world as we know it today but 'worlds' as there are signs of humans conquering outer space and making habitations for not only their own survival but for rich prosperity

In this struggle for prosperity the challenge is that one needs circumspection, to be always up to date, to analyse situations, take precautions, anticipate risks and avoid possible failures. This leads to the need to rapidly update information constantly, throwing away knowledge which may be outdated in the course of a few years.

In order to do this successfully keen Mental and Physical Health are essential aspects that have to be ensured. Everyone needs to be in top form to take advantage of the sophisticated facilities that will be available.

In order to regulate action in a fiercely competitive atmosphere, laws will need to be collectively established and accepted, due processes will have to be put in place and organized action undertaken amiably by mankind. Globalization in its widest sense will be a concomitant feature of all these changes so that no country will escape the ramifications of mutual dependence. Collective knowledge and practices will have to be shared as the world contracts symbolically.

In the working world, in preference to specialized skills, General Basis Skills capable of meeting the challenge of rapid technological advance and change will become essential. Whitehead the eminent philosopher of yester year said, 'The fixed man for the fixed job was a godsend in the past, but he will be a positive menace in the future'. All activity will be in a flux-jobs changing rapidly even before one becomes familiar with routines in any one job. In the face of these rapid challenges all workers will need to change jobs a number of times during their working life. It is Alwin Toffler who said in his famous book 'Future Shock' that unless humankind is equipped with capacities to meet the challenging changes of future life, they will succumb to shock and mental illness. Even now there are signs of what we may expect in the future because many workers are already suffering from the mental stress of overwork and fierce competition. 
In order to be able to withstand these stress factors which are appearing even during the current times, special attention needs to be paid to equip students with ability to accept and adapt to change which gives than the capacity for Flexibility. This special aptitude will ensure that they will not wait for the future to overtake them like a burglar. Instead they will be able to welcome the future as a trusted friend. They will not be shocked by the unexpected and the unforeseen but rather they will sharpen their mental capacities and find ingenious solutions to meet the challenges of unexpected circumstances.

This implies that their natural Creative and Innovative Thinking powers and imagination need to be nurtured and fostered to their utmost limits. It is said that reason can answer questions but one needs imagination to ask them. It was Sri Lanka's famous adopted citizen Dr. Arther C. Clarks's creative imagination that foresaw a number of technological dreams in space travel that have become actualities today. It is indeed an imaginative mind that exclaims. "Some people see things as they are and say 'Why' - but I dream of things that never were and ask 'Why Not?'”

It is creative thinking that sees possibilities in every nook and corner and gives rise to Resourcefulness, a characteristic essential for contented future life. No problems are left unsolved by resourceful people. They see possibilities where others predict doom and failure. To them there are no problems. There are only challenges. There are no failures, only lessons learnt for the future. They dream the Impossible Dream and what is more they even make it come true. They are valuable essential assets to any group which make the whole, not only a combination of the parts, but gives it a vitality and significance of its own.

In tandem with mental skills - or rather even more important - are Personal Attitudes that need to be developed in order that people may lead fruitful and contented lives.

Personal wellbeing depends on one's own Habits and Practices. Self reliance leading to self respect may well be taught through challenging activities early in life. Respect for others and fairness in all dealings will make life congenial and enjoyable. Future citizens need to accept fair criticism gracefully, and be self critical in initiating innovative actions. Total commitment to work and ever striving for excellence to complete one's assignments with finesse are other rewarding activities that enrich one's own life. 
Commitment in the wider sense includes a caring attitude towards one's total environment - fauna and flora included. Protection and nurture of one's surroundings bring up the best characteristics hidden deep within each of us, leading toward friendly well-knit neighbourhoods that support and encourage togetherness among human beings. In the face of the present day highly cut-throat competition that surrounds us caring for those less advantaged than one's own self is an attitude to be cherished and promoted.

In the final analysis, love of one's own Motherland and complete devotion to ensure its welfare to the best of one's ability are undoubtedly immediate and essential qualities we should promote in our young population.

In this 21 st century we desperately need everyone to be proud Sri Lankans, devoid of all divisions of race, creed or language, so that very soon the voice of strife may be dumb and peace and amity may prevail over the whole island.

If we are to reach this treasured target, we should not forget that every teacher from the Primary right up to University level needs to play a significant part in this endeavour. I can state this role in no better words than those of Paulo Freire the famous South American Educationist when he said,

Any group of outside educators who have grown up, lived and studied in a privileged situation must 'die' as a class and be reborn in consciousness - leaning always while they teach and working always 'with' and not 'on' the people they serve'.

As most of us adults are 'teachers' of one sort or another, it is our bounden duty to cultivate many qualities that will help us to fulfil this role. A few of these attributes would be love of students, a fun loving sunny personality, an open mind and readiness to try out new ideas, creativity, humility and readiness to learn, self criticism, a sense of fairness, understanding and accepting individual differences, readiness to show appreciation as well as practising what one preaches.

In fulfilling this role to the best of our ability the road will be hard and arduous. But let us raise our spirits up and with Robert Frost say in earnest, 
$T K J$ Peiris

'The woods are lovely, dark and deep

But I have promises to keep

And miles to go before I sleep'

I thank you for patiently listening to me. 